\title{
THE ROMAN ECONOMY: FROM CITIES TO EMPIRE ${ }^{1}$
}

By

\author{
WILLEM M. JONGMAN
}

\section{The grandeur that was Rome}

The Roman Empire was a vast and populous state. Its size was an order of magnitude bigger than anything else in any period of European history, and only comparable to that of the other world empire of the time, China. The Roman Empire at its peak in the first and second centuries $\mathrm{AD}$, had a population of at least some 60 million people, and perhaps even a bit more. ${ }^{2}$ Again, the only comparison is with the perhaps just a bit less populous Chinese Empire. Between them, these two states ruled perhaps a third or more of the world population of their time. The first modern states to have populations of this size were the United States and Russia, in the late nineteenth century. In the Mediterranean core areas of the Roman Empire population density, moreover, reached levels that would often never be exceeded, or even matched, in later pre-industrial history.

The Roman Empire, however, was not only large and populous; it was also a highly urbanized society. Rome, the capital city, had a population of about 1 million inhabitants. ${ }^{3}$ That is vastly more than was to be normal in medieval or early-modern times. In 1500 only four European cities had more than 100,000 inhabitants. ${ }^{4}$ Between them those four cities had only 450,000 inhabitants. The city of Rome was and remained unique in European preindustrial history. It was by far the biggest city in the world, and remained so until the growth of the big Chinese cities of the Sung dynasty in the eleventh

\footnotetext{
${ }^{1}$ Research for this paper was supported by NWO, The Netherlands Research Council. It was presented at the University of Akron as the 1999 Emily Harpham Memorial Lecture. I gratefully acknowledge the hospitality of my colleagues at Akron, and of my host J. Clayton Fant in particular. I should also like to thank audiences in New York, Leiden, Cambridge, Oxford, Ann Arbor and Stanford.

${ }^{2}$ Classics for the history of aggregate ancient population include K.J.Beloch, Bevölkerungsgeschichte Italiens I-III (Berlin/Leipzig 1937/ 1961); P.A. Brunt, Italian manpower, 225 B.C.-A.D. 14 (Oxford 1971); K. Hopkins, Conquerors and slaves (Cambridge 1978). Recent contributions include W. Scheidel, ed., Debating Roman demography (Leiden 2001). See now also N. Morley 'The transformation of Italy, 225-28 B.C.' Journal of Roman Studies 91 (2001), 50-62 for a discussion of the higher estimates proposed by Elio LoCascio in numerous important articles.

${ }^{3}$ Hopkins 1978, op.cit. (n.2), 96 ff. and W.M. Jongman, 'Roma II: Bevölkerung und Wirtschaft der Stadt Rom' in: H. Cancik \& H. Schneider, eds., Der neue Pauly. Enzyklopädie der Antike X (Stuttgart/Weimar 2001), 1077-1083 for surveys. Non vidi G. de Kleijn, The water supply of ancient Rome. City area, water, and population (Amsterdam 2001).

${ }^{4}$ J. de Vries, European urbanization 1500-1800 (London 1984), 269 ff.: Naples had about 150,000 inhabitants, Milan, Venice and Paris each about 100,000.
} 
to thirteenth century A.D. ${ }^{5}$ The first European city to have 1 million inhabitants again was London, in the early nineteenth century. ${ }^{6}$ Rome, moreover, was not the only big city in the Empire. Together, Carthage, Alexandria and Antioch probably had at least another 1 million inhabitants. All in all, perhaps $5 \%$ of the population of the Roman Empire lived in cities with more than 100,000 inhabitants. Around 1800 , only about $3.3 \%$ of the European population lived in such cities. ${ }^{7}$ Roman urbanism was remarkable for the number of really big cities.

Roman cities were not only large, but also numerous. Administratively, there were at one time 431 cities in Roman Italy alone. It has been estimated that even apart from Rome, about $20 \%$ of the population of Italy lived in cities, although many of them must have been quite small (my estimates imply an average of only about 2000 inhabitants for cities outside Rome). Cities were the centres of civic administration, and the residences of the land-owning elite. The Roman Empire was probably more urbanized than any later period of European pre-industrial history. That is all the more important since urbanization and the size and density of population are often seen as indicators or even engines of economic development. Why then did the Roman Empire fall?

It is important to remind ourselves of the comparative historical magnitude of Rome's achievement. Rome was not a primitive ancestor to the medieval world. On the contrary, on a number of important indicators Rome clearly surpasses anything that would follow until the Industrial Revolution. The bewilderment of Renaissance men about the grandeur that was Rome was genuinely justified: living in Renaissance Rome was like living in New York, a century after a Third World War. ${ }^{8}$

\section{A bleak world without future}

Perhaps more than anyone, it was Sir Moses Finley who reminded us that the story of Rome, however, is not only grand. ${ }^{9}$ It is also a story of appalling mortality for all its population, poverty for the masses, and little

\footnotetext{
${ }^{5}$ M. Elvin, The pattern of the Chinese past (Stanford 1973), $175 \mathrm{ff}$.; Idem, 'Chinese cities since the Sung dynasty', in Ph. Abrams \& E.A. Wrigley, eds., Towns in societies. Essays in economic history and historical sociology (Cambridge 1978), 79-89. The similarities with Roman urbanization are remarkable, just as the differences with medieval Europe.

${ }^{6}$ E.A. Wrigley, 'A simple model of London's importance in changing English society and economy 1650-1750.' In: Abrams \& Wrigley 1978, op.cit. (n. 5), 215-243.

${ }^{7}$ De Vries 1984, op.cit. (n.4), $269 \mathrm{ff}$.

${ }^{8} \mathrm{Cf}$. W.M. Jongman, The economy and society of Pompeii (Amsterdam 1988), esp.15 and 73.

${ }^{9}$ M.I. Finley, The ancient economy (London 1985, $2^{\text {nd }}$ revised ed.).
} 
improvement in the standard of living or productive technology over many centuries. Average life expectancy at birth was probably hardly more than twenty years. ${ }^{10}$ The innovative demographic research of historians like Hopkins, Bagnall and Frier, Saller or Scheidel has offered horrific visions of a world we have fortunately lost. ${ }^{11}$ For me, this represents the most dramatic gain in our understanding - and appreciation - of the ancient world of the last few decades. Mortality was so high because most people were poor and vulnerable to infectious diseases. ${ }^{12}$ Mortality was higher in cities and probably highest in big cities. ${ }^{13}$ People infected each other: living in cities

${ }^{10}$ Of course, this does not mean people did not get older than twenty years (as some still seem to think). The figure is greatly, but certainly not exclusively, influenced by high infant mortality. Average life expectancy increased after the first year of life.

${ }^{11} \mathrm{~K}$. Hopkins, 'On the probable age structure of the Roman population', Population Studies 20 (1966), 254-264 represents the kind of devastating breakthrough which happens only rarely. It has taken a long time before scholars have begun to realize the fundamental nature of the article: K. Hopkins, Death and renewal (Cambridge 1983) uses the methodology with model life tables in a revolutionary analysis of (dis)continuity among the senatorial elite - cf. Jongman 1988, op.cit. (n.8), $317 \mathrm{ff}$. for the ordo decurionum of Pompeii. R.S. Bagnall \& B.W. Frier, The demography of Roman Egypt (Cambridge 1994) founded the subject in ancient sources, but is now criticized in W. Scheidel, Death on the Nile. Disease and the demography of Roman Egypt (Leiden 2001). R.P. Saller, Patriarchy, property and death in the Roman family (Cambridge 1994) added important methodological innovation by using simulation techniques and probabilistic argument. For recent surveys see: T.G. Parkin, Demography and Roman society (Baltimore 1992); W. Scheidel, 'Progress and problems in Roman demography'in: W. Scheidel, ed., Debating Roman demography (Leiden 2001), 1-81; B.W. Frier, 'Demography' in The Cambridge ancient history 2nd ed. XI (Cambridge 2000), 787-816. W. Scheidel, 'Roman age structure', Journal of Roman Studies 91 (2001), 1-25 criticizes model life tables because they disguise the great variation around the mean. That may be true, but a mean may still be useful, depending on the purpose. The important thing is whether the variation is largely random, our according to some identifiable pattern. The importance of Scheidel's work has been that he has gone beyond aggregates, and looked at causes of death.

${ }^{12}$ There is controversy about the relative importance of diet and infectious disease. Scheidel 2001, op.cit. (n.11) suggests the debate is settled, but that is not quite true. See for example R.W. Fogel, 'Nutrition and the decline in mortality since 1700: Some preliminary findings' in: S.L. Engerman \& R. E. Gallmann, eds., Long-term factors in American Economic growth. Studies in income and wealth 51 (Chicago 1985), 439-555 for an eloquent analysis of the importance of nutrition. The causality may well be rather more complex. Of course, infectious diseases are usually the executioners, but often of populations which were significantly weakened by bad nutrition. Therefore, high mortality among Roman emperors (see W. Scheidel, 'Emperors, aristocrats and the Grim Reaper: towards a demographic profile of the Roman élite', Classical Quarterly 49 [1999], 254-81) may be the consequence of infectious diseases fed by a badly fed population. Moreover, the rich may have eaten enough calories, but they may have eaten (and drunk) naughty things which made them unhealthier. See Fogel for the bad eating habits of the English elite, and the alcoholism of their pregnant women.

${ }^{13}$ W.M. Jongman, 'Slavery and the growth of Rome. The transformation of Italy in the first and second centuries BCE', in C.Edwards and G. Woolf, eds., Rome the Cosmopolis (Cambridge, 2003), 100-122; W. Scheidel, 'Germs for Rome', in Edwards and Woolf, op.cit. R. Sallares, Malaria and Rome. A history of malaria in ancient Italy (Oxford 2002) adds to the horrors. A. Scobie, 'Slums, sanitation and mortality in the Roman world', Klio 68 (1986), 399-433 provides a horrific picture of 
was a lethal habit, for rich and poor alike. ${ }^{14}$ In the city of Rome some 50,000 corpses had to be disposed of every year, often in pits, together with dead animals and household refuse. ${ }^{15}$ Some bodies were not even thrown into these puticuli. Suetonius (Vesp. 5.4) tells us that one day (as a portent of Vespasian's future power) a stray dog came in when the future emperor was having breakfast, to drop a human hand from the cross-roads under the table. When Martial (10. 5. 11-12) recounts the fate of a beggar dying in the streets of Rome, and surrounded by dogs and vultures, the point of the story is whether the poor man will be eaten dead or alive. Of the skeletons at a Roman cemetery at Cirencester, more than half were gnawed by dogs. ${ }^{16} \mathrm{~A}$ tomb on the Via Appia was not for everyone. Few societies have such disregard for their dead as to treat them as waste. People were not in short supply.

The standard of living of most Romans was and remained low. High mortality is an obvious indicator, as is the unbalanced diet of the masses. As a sombre Peter Garnsey wrote: 'accounts of the diet and health of ancient classical societies have generally been unrealistically favourable. ${ }^{17}$ Bread itself was a luxury compared to porridge, and only afforded by Rome's conquest of Sicily. Food counted for most of popular private expenditure, and cereals provided the bulk of the calories in this diet. ${ }^{18}$ Rome was and remained an agricultural economy. Not only was consumer demand mostly for agricultural products, but agriculture also occupied most of the labour force. Both aggregate demand and supply were governed by the biological logic of hungry mammals and unyielding and unpredictable food crops.

This low standard of living was not for all. The increasing wealth of the elite and the emperor was both stupendous and unchallenged. Social

the filth and stench of that 'other antiquity'. It should be read by anyone who may feel some scepticism about antiquity as an example for our time, and who needs some revolting anecdotes.

${ }^{14}$ Scheidel 1999, op.cit. (n.12) for the mortality of the rich.

${ }^{15}$ Hopkins 1983, op.cit. (n.11), ch 4 for thick description of death in Rome. The figure of 50,000 assumes a stationary population of one million, and a life expectancy at birth of twenty years. Reality was probably worse. In Jongman, op.cit. (n.13) I argue that Rome needed a large number of immigrants just to maintain its size. Therefore, people came to Rome, to die.

${ }^{16} \mathrm{~A}$. Mc Whirr, et al., Romano-British cemeteries at Cirencester II (Cirencester 1982), $194 \mathrm{f}$. I owe this and other examples to Scobie 1986, op.cit. (n.13).

${ }^{17} \mathrm{P}$. Garnsey, Food and society in classical antiquity (Cambridge 1999), 60.

${ }^{18}$ W.M. Jongman, 'Roma II: Bevőlkerung und Wirtschaft der Stadt Rom, C Lebensmittel versorgung', in H. Cancik \& H. Schneider, eds., Der Neue Pauly. Enzyklopädie der Antike X (Stuttgart/Weimar 2001), 1081-1083 and A. King, 'Diet in the Roman world: a regional inter-site comparison of the mammal bones', Journal of Roman Archaeology 12 (1999), 168-202 for the nuances to this blunt generalization. 
inequality was large and extended well beyond the inequality of incomes. Access to both criminal and civil justice was differentiated between status groups. Slaves had few rights, but increasingly the same was true for ordinary citizens. The great divide was between those who owned land, and those who did not. High population density had made land scarce and expensive, and labour abundant and cheap. The wealth of the elite has disguised the poverty of the masses. When modern historians imagine what it was like to be a Roman, they too easily imagine themselves as senators.

This bleak picture did not change appreciably over time. Perhaps some periods showed mildly improved conditions, but others showed possible deterioration. In the long run, the trend was probably neither considerably up nor down. Even a small per annum growth of per capita incomes should have shown large and unmistakably visible changes in standards of living after a few centuries. ${ }^{19} \mathrm{~A}$ half percent growth would have increased per capita incomes twelve fold after five hundred years. A one percent annual growth, often viewed as a minimum for modern economic growth, increases per capita incomes 144 times over this same period. I do not think anyone would argue that that ever occurred. Technology changed little: it made abundant use of labour that was cheap as result of population pressure and legal oppression. Rome was and remained what has been termed an organic economy, without the technology to use fossil fuels for heat and power. ${ }^{20}$

\section{The spell of Moses Finley}

Ancient Rome presents us with two faces, one of extraordinary achievement, and one of stagnation and underdevelopment. We need not be surprised that scholars have wildly different views of this economy. ${ }^{21}$ I want to argue that current debate on the Roman economy is flawed because it attempts to choose between these two faces of Rome, between 'achievement' and 'underdevelopment'. The so-called 'modernists' are impressed by Rome's achievement; deep in their hearts they cannot accept that such an impressive state could have an underdeveloped economy. The so-called 'primitivists' see the stagnation, and their minds are filled with anthropology and images of small-scale pre-market societies in Polynesia vel sim. The debate has now reached something of a stalemate; neither side has had much new to say in

${ }^{19}$ Cf. R.P. Saller, 'Framing the debate over growth in the ancient economy' in: W. Scheidel \& S. von Reden, eds., The ancient economy (Edinburg 2002), 251-269.

${ }^{20}$ E.A. Wrigley, Continuity, chance and change. The character of the Industrial Revolution in England (Cambridge 1988).

${ }^{21}$ Scheidel \& von Reden 2002, op.cit. (n.19), for the most recent survey. 
recent years, and neither side has convinced the other. I want to argue that this is so because even Finley's 'modernist' critics have been spellbound by his terms of the debate. I also want to argue that they are wrong.

Finley's critics agreed with him that the scale and status of trade and manufacturing were the crucial group of variables. Finley had argued that antiquity was underdeveloped and fundamentally different from some other societies, and in particular from medieval and early-modern Europe, because it lacked 'an enormous conglomeration of interdependent markets. ${ }^{22}$ In antiquity, economic behaviour was governed more by the value systems of social groups than by economic rationality (thus precluding the use of modern economic theory for the analysis of the ancient economy). The prevailing value system largely excluded the elite from trade and manufacturing. As a consequence, and in contrast to the later history of Europe, trade remained the domain of people of low status without the means to realize the potential of commercial growth. Ancient cities were 'consumer cities' rather than 'producer cities'.

Criticism has largely been empirical rather than conceptual. Finley's critics pointed to what are, in their view, clear examples of (sometimes indirect) elite involvement, and of comparatively large-scale trade and manufacturing. The most outspoken critics have often been historians of the Roman Empire, who, perhaps not surprisingly, have found it harder than many historians of archaic and classical Greece to accept the 'primitivist' model of the ancient economy. ${ }^{23}$ Finley's critics, however, tried to play a game they could not win. The more examples of large-scale trade and manufacturing they recounted, the harder it became to explain the ultimate lack of modernization. The Roman world did not have an Industrial Revolution; instead it fell. ${ }^{24}$

Ironically, both Finley and his critics also played the wrong game. They focussed on the scale and status of trade and manufacturing in antiquity because they shared the belief that the later modernization of the European

\footnotetext{
${ }^{22}$ Finley 1985, op.cit (n.9), 22.

${ }^{23}$ But see E.E. Cohen, Athenian economy and society: a banking perspective (Princeton 1992).

${ }^{24}$ Historians of Late Antiquity have tried to deny that the Roman Empire fell, or even declined: it just transformed. They are right to insist that change was complex, and not overnight. To deny the decline is perverse, however. For amusing recent controversy see the responses to J.H.W.G. Liebeschuetz, "The uses and abuses of the concept of "decline" in later Roman history, or Was Gibbon politically incorrect?' in Luke Lavan, ed., Recent research in late-antique urbanism. Journal of Roman Archaeology, Suppl. Series 42 (Ann Arbor 2001), 233-245, plus following pages for responses. See now M. McCormick, Origins of the European economy. Communications and commerce, AD $300-$ 900 (Cambridge 2001) for a new comprehensive synthesis.
} 
economy was due to the emergence of a commercial bourgeoisie and to the increased division of labour between town and country. Finley's The ancient economy has been so important precisely because it gave us a view of the ancient economy in that wider perspective, and gave ancient history its rightful place in the intellectual debates of our times. Sadly, few critics have had such helicopter vision. Sadly, also, I fear that Finley's view of where the ancient economy stands in world history is ultimately wrong. The man who argued that first and foremost is H.W. Pleket. ${ }^{25} \mathrm{He}$ has consistently shown that it is wrong to think of mediaeval and early modern Europe as more highly developed than the Roman world. He is the champion of a longue durée which includes classical antiquity, and which, with perhaps a few exceptions such as Holland, only ends somewhere in the late eighteenth or early nineteenth century.

Inevitably, therefore, the debate on the ancient economy has had an often largely implicit - comparative historical component. It assumed that we know what caused the later growth and modernization of the European economy (the growth of a commercial bourgeoisie, and of trade and markets in manufactured goods), and looked to those parts of the economy for an assessment of Roman achievement. Some, the so-called 'primitivists', said trade and manufacturing were of small scale and low status. Others, the socalled 'modernists', said that, really, the scale and status of trade and manufacturing were rather more substantial. But what if the later economic modernization and growth of the European economy actually had rather different causes, and a different course? That, indeed, is the drift of much recent scholarship on European economic history. Robert Brenner and Jan de Vries, for example, have in quite different ways drawn our attention to rural social relations and changes in agriculture. ${ }^{26}$ Sir Tony Wrigley has once again insisted on the essential discontinuity of modern economic change. ${ }^{27}$ For him, the Industrial Revolution is both industrial and revolutionary. Therefore, we are now in a different game, with different goals. If trade, traders and markets mattered less to the later modernization of the European

\footnotetext{
${ }^{25}$ H.W. Pleket, 'Wirtschaft', in W. Fischer, et al., eds., Handbuch der Europäischen Wirtschafts- und Sozialgeschichte I: F. Vittinghoff, ed., Europäische Wirtschafts- und Sozialgeschichte in der römischen Kaiserzeit. (Stuttgart 1990), 25-160; W.M. Jongman \& M. Kleijwegt, 'H.W.Pleket, epigraphist and comparative historian', in W.M. Jongman \& M. Kleijwegt, eds., After the past. Essays in ancient history in honour of H.W. Pleket. (Leiden 2002), ix-xxiv.

${ }^{26} \mathrm{R}$. Brenner, 'Agrarian class structure and economic development in pre-industrial Europe', Past and Present 70 (1976), 30-75; J. de Vries, The Dutch rural economy in the golden age, 1500-1700 (New Haven 1974).

${ }^{27}$ Wrigley, 1988, op.cit. (n.20).
} 
economy, their small scale and low status also matter less for our understanding of the ancient economy. Ancient historians may have wasted their time on the wrong questions.

\section{Exchange and the longue durée}

With the growth of the Roman Empire, a much larger economic system emerged than had existed before. The spoils of empire began to be fed into the Italian economy, allowing an unprecedented growth of cities and, undeniably, more trade. Particularly expressive have been two famous graphs from Keith Hopkins' article on taxes and trade. ${ }^{28}$ In one, he shows the enormous growth in Roman silver coinage in the Late Republic. In the other, he plots the rise (and later decline) of Roman shipping in a count of the number of dated shipwrecks per period. How did this increased economic integration and exchange transform the economy, and did it generate growth and development? Did it allow (at least some parts of) the Roman Empire to escape some of the niggardliness of nature?

What I want to do is inspect three instances where this may have been the case. The first is in agriculture. Did the growth of a large Italian urban market for food transform Italian agriculture? The second is textile manufacture. Did the growth of an urban market stimulate the emergence of urban manufacturing for external markets of a kind witnessed in medieval and early-modern Europe? Third, does the increased volume of Roman coinage point to higher levels of monetization and to a larger volume of transactions? What I shall try to argue in all three cases is that we would be wrong to underestimate the scale and complexity of the Roman economy. However, I also want to argue tentatively that what we have is not quite economic growth and development either. In each case, I shall argue that what we see has little to do with Adam Smith's eulogy on the benefits of division of labour and exchange. The Empire was a large unit, so the Roman economy was large and complex. It did not, however, obviously escape the limits to growth imposed by nature and technology.

Agriculture was and remained the most important sector of the Italian economy. Some scholars have argued in recent years that Roman urbanization and the integration of the Roman economy created scope for specialized and market oriented agriculture. The city of Rome in particular,

${ }^{28} \mathrm{~K}$. Hopkins, 'Taxes and trade in the Roman Empire (200 B.C.- A.D. 400)', Journal of Roman Studies 70 (1980), 101-125, esp. 109 and 106. 
they argue, was a huge market encouraging the specialized production of vegetables, wine and oil. ${ }^{29}$ Indeed, it belongs to the stock of traditional knowledge taught by all of us that, from the late Republic, large tracts of Roman Italy were turned into vineyards owned by the rich. For Hopkins, that was one of the economic advantages of Roman imperialism. However, I think the model is wrong, and fatally dependent on tendentious literary sources. ${ }^{30}$ Instead, we should try to estimate what was a probable maximum demand for wine, and see how that could be produced. The advantage of the methodology is that we do not need ancient sources for what are essentially biological parameters. Of course these are only rough estimates. Yet, with them the range of the possible is often much narrower than we might be able to establish from ancient sources. The total thirst of the city of Rome, for example, may have been satisfied from an area of about 50000 hectares of vineyards. That is an area of about $23 \mathrm{~km}$ square. For all of Italy, under average Roman conditions about $5 \%$ of agricultural land in Italy was enough to produce a bottle a day per Italian adult. Therefore, it is unlikely that Italy was ever transformed into one large vineyard.

Roman agriculture was undoubtedly quite sophisticated. Members of the elite wrote manuals on estate management, and small farmers tended their land with great dedication. Every traveller to the Mediterranean region has seen the ancient terracing of now barren and unused hillsides, bearing witness to the hunger for agricultural land, and the toil required. Agriculture was able to feed a large population, and that was its great achievement. In some areas of the Empire it could feed populations up to about 200 people per square kilometre. ${ }^{31}$ In Egypt, agricultural output was even higher. ${ }^{32}$ And yet, there was a chilling downside. In recent years, scholars including myself have argued that many Roman peasants did not normally use oxen for the heavy work. ${ }^{33}$ Economically, their plots were too small to support an ox (the terraces to which I just referred offered physical obstacles as well). The labour savings an ox would have brought were meaningless to peasants

\footnotetext{
${ }^{29}$ K. Hopkins 1978, op.cit. (n.2), chapters I and II; Hopkins 1980, op.cit.(n.28); Keith Hopkins, 'Rome, taxes, rents and trade', Kodai. Journal of Ancient History 6/7 (1995/1996), 41-75, now conveniently reprinted in Scheidel \& Von Reden 2002, op.cit. (n.19), 190-230. Also, H.W. Pleket, 'Rome: a preindustrial megalopolis', in Th. Barker \& A. Sutcliffe, eds., Megalopolis: the giant city in history (London 1993), 14-35, and N. Morley, Metropolis and hinterland: the city of Rome and the Italian economy (Cambridge 1996).

${ }^{30}$ More extended argument in Jongman, op.cit. (n.13).

${ }^{31}$ Jongman 1988, op.cit. (n.8), esp. 131-137.

${ }^{32}$ Scheidel 2001, op.cit. (n.11), 224 ff. for yields and 115 for population density.

${ }^{33}$ Jongman 1988, op.cit. (n.8), 83-4, 152, 201; W.M. Jongman 'Viehzucht: Rom' in: Der Neue Pauly.
} 
whose own labour and that of their families was not fully employed, and available at zero cost. So rather than ridding themselves of part of their family and improving their labour productivity by using an ox, they and their family worked the land with spades and hoes. Thus they probably achieved remarkable yields per hectare, growing cereals in almost horticultural fashion, but at the price of long and hard toil. It is a model which demonstrates that ceilings on production can be breached, but at a price. ${ }^{34}$ That price was paid when circumstances required it, when, for example, in the family lifecycle adolescent children needed much food, and when their labour was freely available. High production per hectare was achieved at the expense of labour productivity and standard of living.

Roman agricultural underdevelopment should in my view be analysed most of all in terms of various physical constraints. Rather than worry about the mentality and rationality of Roman landowners, we should, I think, be concerned with the physics and biology of low returns in agriculture within particular climatic systems and on specific soil types, with variability due to bad weather, with the effects of malnutrition and disease, or with the dependence on organic sources of heat and power. In short, with man's inability to reach much beyond other mammals and overcome the rule of nature.

Of all branches of the medieval and early-modern economy, textile manufacturing and trade have been most important for the debate on economic growth and development. Yet, the Roman textile industry has not been served well by ancient historians. I have argued recently that, unlike in medieval and early-modern Europe, the Roman textile industry was not concentrated in a few centres which specialized in production for distant markets. ${ }^{35}$ Given prevailing technology, there were no economic advantages to such concentrated production. So, instead, production of cloth was distributed across the many urban centres of consumption, allowing close contact with consumers. What was concentrated, however, was the production of better quality raw wool in areas of relatively low population

\footnotetext{
${ }^{34}$ P. Halstead, 'Traditional and ancient rural economy in Mediterranean Europe: plus ça change?' , Journal of Hellenic Studies 107, 77-87, now reprinted in Scheidel \& Von Reden 2002, op.cit. (n.19), 53-70, for the best analysis of the great variation that was possible.

${ }^{35}$ W.M. Jongman, 'Wool and the textile industry of Roman Italy', in E. Lo Cascio, ed., Mercati permanenti e mercati periodici nel mondo Romano. Atti degli incontri Capresi di storia dell' economia antica (Capri 13-15 ottobre 1997). Pragmateiai 2 (Bari 2000), 187-197. See now also the thoughtful contribution by S. Dixon: 'How to count them if they're not there? New perspectives on Roman cloth production' Opuscula romana 25-26 (2000-2001), 7-17.
} 
density, and generous pastures. The trade that there was, was of wool rather than cloth. ${ }^{36}$

This goes to show that the Roman Empire was not a conglomerate of Polynesian islands, but it also shows that more trade and division of labour are not necessarily economically advantageous. What matters is the balance between the costs and benefits of increased specialization. Both are physically constrained by nature, and technological possibilities. Of course, pointing to such constraints does not explain everything (they could be overcome, and ultimately were - in recent times) but serves to underscore that what people did made sense. There were no easy fixes. ${ }^{37}$

The integration of production and consumption into a system of interdependent markets has been an important part of the debate on the ancient economy. Was it an integrated market economy, or not? Part of that discussion is about the goods themselves, of course. Was there much division of labour and specialization between regions, and were prices interconnected? With prices, we enter the other part of the discussion: how monetized was the Roman economy ? $^{38}$ Monetary integration greatly facilitates market integration. As we have seen, Keith Hopkins argued that the growth of the Empire in the late Republic witnessed an enormous monetary expansion. Indeed, in his Money and government Richard DuncanJones arrives at the important conclusion that Rome's monetary stock was much larger than we ever thought, and was perhaps equal to between one and two times (our best estimates of) Gross National Product. ${ }^{39}$ Moreover, of the value of this monetary stock some two-thirds was in gold coins. Whatever the precise value of such estimates, it is now more difficult to maintain that Rome was an under-monetized economy. Here, a historical comparison may be revealing. In the seventeenth and eighteenth century, the money supply of the Dutch Republic was largest of any European economy:

\footnotetext{
${ }^{36}$ This view has now been challenged by F.Grelle \& M.Silvestrini, 'Lane apule e tessuti canosini', in Epigrafia e territorio. Politica e società. Temi di antichità romana VI (Bari 2001), 91-136.

${ }^{37}$ W.M. Jongman, 'Hunger and power. Theories, models and methods in Roman economic history', in A.C.V.M. Bongenaar, ed., Interdependency of institutions and private entrepreneurs. Proceedings of the second MOS symposium, Leiden 1998. Nederlands Historisch-Archaeologisch Instituut te Istanbul: MOS Studies 2 (Istanbul 2000), 259-284, esp. 280 for the need to avoid prescriptive patronizing of our ancestors.

${ }^{38}$ M.H. Crawford, 'Money and exchange in the Roman world', Journal of Roman Studies 60 (1970), 40-48 is the primitivist classic. Cf. Hopkins 1980, op.cit. (n.28) and Idem 1995/1996, op.cit. (n.29); S. von Reden, 'Money in classical antiquity: a survey of recent literature' Klio 84 (2002), 141- 174.

${ }^{39}$ R.P. Duncan-Jones, Money and government in the Roman Empire (Cambridge 1994), esp. 168-170; Hopkins 1995/1996, op.cit. (n.29), 45-48.
} 
it may have just exceeded half of Gross Domestic Product. To the best of our knowledge, therefore, Roman money supply may be unrivalled in any period of European pre-industrial history.

Perhaps counter-intuitively, however, I want to maintain that this large money stock reflects Rome's lack of development. ${ }^{40}$ Roman money supply was far larger than was needed for ordinary transactions. Moreover, the gold coins were too valuable for that: an aureus was worth HS 100, which would buy almost a year's subsistence for any average Roman. The gold coins were largely held and used by the rich. So why did the Romans hold such large cash reserves in (gold) coin? Of itself, holding idle cash is not attractive, unless there are specific reasons. Economists distinguish three motives for the demand for money: the transaction motive, the precautionary motive and the speculative motive (which actually refers to the aversion to be forced to speculate with one's assets). What I want to argue is that it was precisely the dangers and uncertainties of pre-industrial life that motivated the Roman elite to hold large cash balances, rather than the need to facilitate a very high volume of ordinary transactions of consumer goods and services.

Elite mortality was high: as Richard Saller has recently shown, perhaps a third of Roman real estate was held by orphans. ${ }^{41}$ Mortality was also unpredictable: either there were too many children, or there were too few because they had all died. Therefore, long lineages were real exceptions. The long-term stability of high mortality and high natality at population level hided great discontinuity at the level of individual families. Without primogeniture (and with daughters receiving substantial inheritances and cash dowries as well), estates had to be divided between children. Property changed hands frequently, and was often split up. That required a lively real estate market, and large sums of money to settle inheritances and property deals. ${ }^{42}$ With some of the family capital in cash, such divisions were far easier. Since inherited wealth provided the bulk of elite income, the value of such transactions was large relative to national income. ${ }^{43}$ It paid to hold large

\footnotetext{
${ }^{40}$ More extended argument in W.M. Jongman, 'A golden age. Death, money supply and social succession in the Roman Empire', in E. Lo Cascio, ed., Credito e moneta nel mondo Romano (Bari, forthcoming).

${ }^{41}$ Saller 1994, op.cit. (n. 11), 189 f.

42 J. Andreau, Les affaires de monsieur Iucundus (Rome 1974), esp. 116 argues that disposal of property and inheritances in particular were important sources for the auctions of the Pompeian auctioneer L. Caecilius Iucundus. Also Jongman 1988, op.cit. (n.8), 216-224.

${ }^{43}$ A numerical example will illustrate this clearly. If the annual return on elite landed wealth was $5 \%$, and if their estates were sold once every twenty years, the annual value of these property transactions equaled annual elite estate income.
} 
cash balances as a precaution, the more so since the banking system was not quite capable of coping with these large sums. Selling assets when necessary may not always have been an attractive alternative. When many members of the elite experienced a need for cash at the same time, assets could rapidly loose their value (the 'speculative motive'). The enormous volume of gold coin was needed because Rome's elite was stupendously rich and very mortal.

\section{Growth and productivity}

Ancient economic historians have been wrong to narrow their discourse to one on trade and markets. There is much more to say about the Roman economy than trade and traders, and there is much more that is important for the real question: how well did the Roman economy succeed to satisfy the wants of the Roman people? Did it do this better or worse than other preindustrial European economies, or just differently? Did it get better at this, and if not, why not? In short, the debate is really about economic growth, and that involves a much wider range of problems than ancient historians have allowed. ${ }^{44}$ However, the debate on the ancient economy has not only been marred by the selective vision of modernists and primitivists who could only see their favourite half of ancient reality. It has also been marred by terminological and theoretical confusion about precisely the concept of growth. Increases in aggregate production, a growth in the area under agricultural cultivation, or a growth in the production and diffusion of particular goods and services that may arguably serve as markers for the economy at large, have all been quoted as indicative of some measure of economic growth. Indeed, the scale of things Roman was often large.

For an economist, such expansion in the scale of economic life is not necessarily the same as economic growth and development. For that, two conditions must apply. The first is a sustained increase in aggregate production and consumption. The second is that this growth in national income outstrips population growth; as a result per capita incomes increase. This rise in the standard of living of the population must continue over a longer period of time, and a large proportion of the population must benefit from this increase in average income.

\footnotetext{
${ }^{44}$ For this, P. Millett's 'Productive to some purpose? The problem of ancient economic growth', in D.J. Mattingly \& J. Salmon, eds., Economies beyond subsistence in the classical world (London/New York 2001), 17-48 is fundamental, and should really be the starting point for all further discussion of the ancient economy. Also Saller 2002, op.cit. (n. 19), and P. Temin, 'Growth theory for ancient historians', in W.M. Jongman \& W. Scheidel, eds., Debating the Roman economy (forthcoming).
} 
Historically, and until the Industrial Revolution, these conditions did not apply at the same time. ${ }^{45}$ Economies expanded when their populations grew and worked harder, to bring more land under cultivation, and work that land more intensively. In the thirteenth century in Europe, aggregate production and consumption were higher than they had probably ever been, and would be for quite a long period. It is wrong, however, to call this expansion growth, because such periods of expansion coincided with a declining standard of living for the mass of the population. Land had become quite scarce, and labour abundant. So rents were high, wages low, and social inequality large. In the fourteenth century, therefore, the Black Death was a blessing in disguise for the survivors. It made labour scarce, and land abundant. So rents plummeted, wages rose, and social inequality was reduced. However, to call such contraction economic growth is just as wrong.

Behind this conceptual confusion about growth lurks confusion about the concept of productivity. Productivity is commonly though incorrectly equated with production. People write of increases in agricultural productivity when they mean to say increases in aggregate agricultural production. Productivity as a concept in economic theory, however, is always related to a specific factor of production, be it labour, land or capital. So, marginal labour productivity denotes the extra output from using one extra unit of labour - with an unchanged amount of land and capital, the other factors of production. The tragedy of human life is that such marginal productivities tend to decline. So even if aggregate production can be increased by using more land, labour and capital, output does not increase by the same proportion as input. Moreover, the supply of factors of production is not equally elastic: the supply of land in particular is highly inelastic. Once all attractive land has been brought under cultivation, only less attractive (i.e. less fertile, or inconveniently located) land remains. Thus, extra demand for land largely increases its price, rather than the quantity on offer. Therefore, beyond quite low density levels, population pressure changes the proportions in which factors may be used, and the ratio of labour to land in particular. However, the more labour we use on a given piece of land, the less extra output we may expect from each additional unit of labour. This means that farmers can increase their production, but only at the expense of declining labour productivity. That is important, because, theoretically, wages are

${ }^{45}$ Jongman 1988, op.cit. (n.8), 76 f., 151 f.; Jongman \& Kleijwegt 2002, op.cit. (n.25). 
equal to this marginal productivity of labour. A higher output is realized at the expense of a lower standard of living for labour.

In principle there are two ways to avoid this trap. The first is to use more of the other factors of production. Normally, that is not possible with land, as its supply is so inelastic. Here, the only possibilities were misappropriation and conquest; these were indeed effective and unquestioned parts of ancient life. A more 'modern' alternative would have been to use more capital. For an economist like Walt Rostow, that was in fact the crucial change in the beginning of the Industrial Revolution. ${ }^{46}$ In pre-industrial agriculture, however, the scope for this is limited. One way would be to sow more seed. By doing this, farmers may increase the production per hectare a bit (at the expense of the sowing ratio). ${ }^{47}$ More and better draught animals probably represent the best opportunity, but they also eat food and thus compete with humans, and members of a peasant's household in particular. ${ }^{48} \mathrm{We}$ shall return to them.

The second way is improved technology, or as the economist would say, a change of the production function. With improved technology, the same amounts of land, labour and capital can produce more output. This can be from improved organization and division of labour, but also from technological innovation of the more physical kind such as the invention and introduction of the steam engine. Here, I have an admission to make: for years I taught that the first was really much more important than the latter, and that change, therefore, was slow. Thus, the Industrial Revolution was neither industrial nor revolutionary. However, as any archaeologist and ancient historian knows, it is dangerous to pronounce on a site if you have never actually seen it. So when I was on a visit to Sheffield I decided to visit some museums of industry. I was overwhelmed by the images of radical change in the technology and organization of production. Within a period of no more than a few decades the Sheffield metal industry had changed from a mostly artisanal technology and organization to big factories with gigantic machines. For me, that was a highly visual and dramatic mark of the end of the world of the longue durée. Shortly afterwards, I read Sir Tony Wrigley's Continuity, chance and change, which gave the argument and the analysis to

${ }^{46} \mathrm{~W} . \mathrm{W}$. Rostow, The stages of economic growth: a non communist manifesto (Cambridge 1993, $3^{\text {rd }}$. ed.).

${ }^{47}$ This shows that the seed:yield ratio is not just a measure of technological achievement, but also of intensification. A high ratio may indicate great achievement, but also a choice for low-intensity farming.

${ }^{48}$ Jongman, op.cit. (n.33). 
match my gut feeling. ${ }^{49} \mathrm{He}$ demonstrated that the change was indeed rapid, and depended on the introduction of fossil fuels as sources of heat and power.

\section{Political economy}

The Roman economy, however, did not escape the constraints of the longue durée. In many respects the lives of ancient Romans were not unlike those of their twelfth or eighteenth century descendants. Life was brutish and short, hunger was an ever-present danger, and diets were mostly simple. Work was hard, and social inequality was large. Agricultural technologies and yields did not change much over the course of many centuries.

I also think, however, that that is not where the story ends. After all, there were also large differences with medieval or early modern Europe. As I argued earlier, the Roman world shows some extraordinary achievements such as a high population density in many areas of the Empire, unprecedented urbanization or political and economic integration. So, the Roman world was different, but not a primitive ancestor - on the contrary. The focus on the scale and status of trade and manufacturing is unfortunate because it cannot explain what sets Rome apart: its extraordinary achievements within what clearly remained a pre-industrial and underdeveloped economy.

What we need is a model that allows us to see both sides of the ancient reality, rather than one part at the expense of the other. What we need is a model that makes sense of precisely the combination of Roman achievement and underdevelopment. What I now want to illustrate tentatively is that if we can hardly underestimate the scale of Roman achievement, it was scale rather than development which marked the economy of the Roman Empire: under certain conditions pre-industrial economies can produce momentous achievements, but these were not the beginnings of growth and development - on the contrary. I shall also try to argue and illustrate that the scale of the Roman economy has everything to do with the enormous size of the Roman empire, unique in pre-industrial European history. It was the scale of the political unit that allowed for the scale of at least some aspects of the economy.

Roman urbanization was and remained unprecedented for a preindustrial state, an observation comfortably ignored by most 'primitivists'.

${ }^{49}$ Wrigley 1988, op.cit. (n.20). 
Why could Rome be so urbanized? A first reason may be that its cities were primarily based on landed wealth. As we know, administratively, town and country were one. Even when we allow for exceptions and some modernist revisions, most of us will agree that for a long time, the landowning elite and the urban elite were largely one and the same social group. It was landed wealth that was the basis of the really large fortunes, in Rome, and, we may add, in later pre-industrial Europe. Roman cities were large and many because they were the central places of the power system, and were not, as Postan said of medieval cities, 'non feudal islands in a feudal sea. ${ }^{50}$ Roman urbanism could be so substantial precisely because it drew on the exploitation of agriculture, the central sector of the economy.

Roman cities were not only large and many, and inhabited and dominated by a different set of people, they also looked different from later pre-industrial cities. The scale of public - and sometimes private - building exceeded almost anything that was to come. ${ }^{51}$ For example, the passion for the extravagant use of water for fountains or baths was both expensive and full of political meaning for those living in a dry climate. Aqueducts were frightfully expensive showpieces of Roman engineering skill, in nearly all cases requiring imperial funding. It has recently been calculated that the Baths of Caracalla may have cost the equivalent of 120,000-140,000 tons of wheat-equivalents to build them - enough to provide a year's subsistence to more than half a million people. ${ }^{52}$ Many public buildings were exquisitely ornated with expensive materials: within a few centuries, the Romans quarried more marble than has been quarried in all centuries since. ${ }^{53}$ The archaeology of Roman urbanism thus gains an importance well beyond the symbolic and cultural. Building is an expensive burden in any society, but

\footnotetext{
${ }^{50}$ M.M. Postan, The medieval economy and society (Harmondsworth 1975), 239. Of course this leaves questions: why did the Roman elite prefer to live together in cities (a quite lethal habit), and why did later aristocracies prefer rural isolation? Here we shall leave them aside.

${ }^{51} \mathrm{H}$. Jouffroy, La construction publique en Italie et dans l'Afrique romaine (Strasbourg 1986); M.T. Boatwright, Hadrian and the city of Rome (Princeton 1987); A. Kolb, Die kaiserliche Bauverwaltung in der Stadt Rom: Geschichte und Aufbau der cura operum publicorum unter dem Prinzipat (Stuttgart 1993).

${ }^{52} \mathrm{~J}$. Delaine, The baths of Caracalla. A study in the design, construction, and economics of large-scale building projects in imperial Rome. Journal of Roman Archaeology, Suppl. Series 25 (Ann Arbor 1997), 207-226 for these and other building costs.

${ }^{53}$ Excellent surveys in H. Dodge, 'Ancient marble studies: recent research'. Journal of Roman Archaeology 4 (1991), 28-50; J. Clayton Fant, 'Ideology, gift and trade: a distribution model for the Roman imperial marbles' in: W.V. Harris, The Inscribed Economy. Journal of Roman Archaeology, Suppl. Series 6 (Ann Arbor 1993), 145-170; P.F.B. Jongste, Het gebruik van marmer in de Romeinse samenleving (Leiden 1995).
} 
particularly in a pre-industrial economy with only few resources available beyond quite bare subsistence for many. The Roman building craze clearly testifies to a strong commitment on the part of its ruling elite and their emperors. Sometimes the urban poor supplied the workforce, both paid and as a community service. At other times it was convict labour, or soldiers with nothing else to do. Special building materials such as extra long wooden beams or rare marbles required an imperial beneficium. Distribution maps of virtually any kind of building show a recurrent pattern of a heavy concentration in the political core of the Empire: the central regions of Italy. ${ }^{54}$ Outside this area, heavy building activity can be found where and when allegiance to Rome must be underscored, such as in provincial capitals, when an area became Roman, or when, for example, it gave the empire an emperor. Both emperors and local elites were able and willing to adorn the urban landscape.

Economically, the Empire's many cities were undoubtedly linked by some long-distance trade. Fairs and markets supplied goods from distant origins. ${ }^{55}$ The Mediterranean provided a relatively cheap conduit for bulk transport, and for shorter distances and inland destinations Roman roads would be unsurpassed until recent times. It will not do to disregard their economic importance because they were built with military and administrative intentions; equally it would be unwise to forget that they were built because the state had to overcome the disadvantages of its large size. It had to reduce the delays in travel and in the spread of information if it wanted to survive. Its size was both a military advantage, and a drawback. For survival, it had to reduce the friction of distance, even at a high cost. Military transport and the cursus publicus were essential state services. That cost may in fact have been quite low: Roman roads were mostly built by soldiers who had nothing better to do.

Finally, this brings us to the exceptional character of the Roman state itself. It covered a large territory, existed for many centuries as a world empire, and represented a level of cultural homogeneity and administrative

\footnotetext{
${ }^{54}$ Jouffroy 1986, op.cit. (n.50).

${ }^{55} \mathrm{~L}$. de Ligt, Fairs and markets in the Roman Empire. Economic and social aspects of periodic trade in a pre-industrial society (Amsterdam 1993) argues that Roman markets were no less important than medieval ones. That may be so (although his dossier of 'markets' often consists of fairs rather than markets), but conceptually the problem is that periodic markets probably were a sign of lack of integration, rather than the opposite. Peter Temin, 'A market economy in the Early Roman Empire', Journal of Roman Studies 91 (2001), 169-181 for a fascinating but at times anachronistic perspective from a modern economic historian.
} 
sophistication that would set an example for a long time after. As Marx saw only too well, in a world without growth, increased prosperity will have to be at someone's expense. In the Roman world, this process had two strands. The first was the large social inequality within the central regions. Here, a neo-classical economic analysis such as I once gave of high rents and low labour productivity in Pompeii under high population pressure, may well provide the logic to understand how the misery of the mass of the population could go hand in hand with the wealth of the rich, and the intensity and scale of the Roman economy. ${ }^{56}$ Population pressure had made land scarce. Therefore, landownership marked the 'haves' from the 'have nots'. The demographic forces at work in the labour market were reinforced by sociopolitical and legal pressures on the status of rural labour. Income and wealth were transferred from the country to the cities.

The second strand was that of Roman imperialism. Rome was the perfect warrior state. The gains in the initial phases of conquest were considerable, and sometimes even exceptional. After that, a system of quite effective taxation developed. The various estimates suggest that in the imperial period Rome collected taxes at the upper end of the range commonly found in pre-industrial societies. ${ }^{57}$ The concentration of these resources in a single hand allowed for unprecedented concentrations of public expenditure. Something like half this public expenditure went to the army. As we have seen, because this was a professional standing army, quite a bit of this military expenditure was turned into infrastructural projects, in Italy, but most of all in the provinces. The other half of public expenditure was spent on the imperial court, on the administration of the empire, and on benefits to the population. These imperial benefits were selective. In the early Empire the city of Rome and the cities of Italy were the main

\footnotetext{
${ }^{56}$ Jongman 1988, op.cit. (n.8), esp. 85-95, 199-203.

${ }^{57}$ Jongman 1988, op.cit. (n.8), 22-23, based on estimates from Hopkins 1980, op.cit. (n.28), 119 ff., who himself calls these taxes low. See now also Hopkins 1995/1996, op.cit. (n.29) for the most recent discussion of the size and composition of public expenditure, with references to earlier contributions. The size of military expenditure is relatively secure and uncontroversial. In his work on Money and Government, cited above in note 39, R.P. Duncan-Jones even thinks of about $77 \%$, but that may be exaggerated. The magnitude of other public expenditure really is no more than a wild guess, only constrained by historical comparisons, and by the implications for the tax rate and GDP: if public expenditure was significantly less than twice military expenditure (which would be historically unusual), we must assume remarkably low taxation levels, and/or a GDP that was little more than bare subsistence for nearly all. In the same article Hopkins rightly draws our attention to the competition between rents paid to the elite and taxes paid to the state. With time, the Roman rich really grew much richer, probably partly at the expense of the state.
} 
beneficiaries of distributions of food and money, and of public building. ${ }^{58}$ Moreover, they were exempted from taxation. The Empire generated a major transfer of income and wealth, from the countryside to the cities, and from the periphery to the centre. ${ }^{59}$

I want to conclude, therefore, with the working hypothesis that the achievement that there was, was mostly that of the Roman state. It was the achievement of an underdeveloped economy driven hard towards the concentrated support of one of the few world-empires of pre-industrial history.

\section{Churchill College Cambridge, April 2002}

\footnotetext{
${ }^{58}$ For discussion and further extensive bibliography on distributions: Jongman 1998, op.cit. (n.37); W.M. Jongman, 'Cura annonae' in H. Cancik \& H. Schneider, Der Neue Pauly. Enzyclopädie der Antike III (Stuttgart/Weimar 1996), 234-236; W.M. Jongman, 'Beneficial symbols. Alimenta and the infantilization of the Roman citizen' in Jongman \& Kleijwegt 2002, op.cit. (n.25), 47-80. See Jouffroy 1986, op.cit. (n.51) for public building.

${ }^{59}$ The state was not the only beneficiary of this transfer from the periphery to the centre. The imperial elite grew increasingly rich, and much of this wealth was due to Empire. In the earlier stages this indeed implied a transfer of income and wealth from periphery to the Italian centre. With time, the elite became increasingly less Italian. For us, it does not matter whether this was because provincials reached the senate (they did), or that senators moved their interests and residences to the provinces (they did). The result is the same: the elite became increasingly an empire-wide elite, extracting surpluses all over the Empire, and investing or consuming them locally. Hopkins 1995/1996, op.cit. (n.29), $206 \mathrm{ff}$ and Jongman 1988, op.cit. (n.8), 189 for diverging accounts of the implications for the 'Taxes and trade' model. A thought experiment may be interesting. Let us assume that the provinces were taxed at $10 \%$ of their GDP, and let us assume that the capital value of provincial assets (mostly land) was ten times higher than GDP (i.e. I assume, for example, a GDP which is twice subsistence, and a return on investment of $5 \%$ ), then taxes could be paid by an annual transfer of $1 \%$ of provincial assets. Of course, not all taxes were paid by the transfer of assets. However, the time frame implied by these figures clearly suggests that asset transfer to members of the Roman elite could easily have made a significant contribution to the payment of taxes, and could have produced an imperial aristocracy with assets all over the Empire within a period of two or three centuries. Once that had happened, taxation became a much harder job for emperors. With Hopkins, I agree that this emergence of an Empire-wide elite is what is reflected in the stupendously increased wealth of the elite.
} 